\title{
FOLIC ACID AND OTHER ABSORPTION TESTS IN LYMPHOSARCOMA, CHRONIC LYMPHOCYTIC LEUKAEMIA, AND SOME RELATED CONDITIONS
}

\author{
BY \\ W. R. PITNEY, R. A. JOSKE,* AND NORMA L. MACKINNON \\ From the Department of Haematology, Royal Perth Hospital, and the Department of Medicine, University \\ of Western Australia, Perth, Western Australia
}

(RECEIVED FOR PUBLICATION MAY 11, 1960)

An improved folic acid absorption test is described in detail.

Using the folic acid and other absorption tests, a study of intestinal function has been made in eight patients with lymphosarcoma, eight with chronic lymphocytic leukaemia, two with Hodgkin's disease, and one each with reticulum cell sarcoma, Whipple's disease, and macroglobulinaemia. It was found that laboratory evidence of intestinal malabsorption was extremely common in patients with this group of diseases.

The folic acid absorption test was the most sensitive single index of malabsorption of the tests used in this study.

Correlation between the different absorption tests was poor, and there does not appear to be a characteristic biochemical profile of intestinal function in these patients.

The pathology and clinical features of primary lymphosarcoma and allied tumours of the alimentary tract have been described by several authors, including Spellberg and Zivin (1949) and Skrimshire (1955). These tumours are uncommon, but may produce dyspepsia, gastrointestinal haemorrhage, or intestinal obstruction. A rare complication is the development of steatorrhoea and overt malabsorption. This was first described by Fairley and Mackie (1937), and the relevant literature has recently been reviewed by Sleisenger, Almy, and Barr (1953), who reported four further cases.

In the majority of patients with lymphosarcoma, involvement of the gastrointestinal tract and mesenteric lymph nodes is an incidental pathological finding associated with infiltration of many other tissues. It rarely produces significant. symptoms, and is not regarded as important in the natural history of the disease. In a recent patient (As) who underwent splenectomy for acquired haemolytic anaemia associated with lymphosarcoma, we were impressed by the appearance of stiffened oedematous bowel at operation, although the patient had noted only slight symptoms of intestinal dysfunction. We therefore decided to investigate intestinal function in an unselected

\footnotetext{
*Adolph Basser Research Fellow in Medicine, Royal Australasian
} College of Physicians. series of patients with lymphosarcoma not arisingo primarily in the alimentary tract. Since somewhat similar infiltration of the intestinal wall and mesenteric lymph nodes may also occur in patients with chronic lymphocytic leukaemia, patients with this condition were included in the investigation.

Special emphasis has been given to the folic acid absorption test, as Chanarin, Mollin, and Anderson (1958) reported that injected folic acid was cleared from the plasma more rapidly than normal in some patients with leukaemia and related disorders. These patients had an associated megaloblastic anaemia, and it was considered that the anaemia was due to folic acid deficiency. Proliferating neoplastic cells have greater than normal requirements for folic acid (Swendseid, Bethell, and Bird, 1951); however, Chanarin and his colleagues noted that some patients failed to absorb folic acid normally.

The present paper describes in detail the folic acid absorption test used in this laboratory, and reports the results of several intestinal absorption tests in patients with lymphosarcoma and related conditions, comparing these to folic acid absorption and the clinical state of the patient.

\section{Methods}

Folic Acid Absorption Test.-The folic acid absorption test was performed as follows. 
Preparation of the Subject.-The subjects were loaded with folic acid before the test. This was achieved in normal control individuals by giving $15 \mathrm{mg}$. folic acid orally on each of the fourth, third, and second days before the test. In patients in whom the absorption of folic acid was to be studied, $15 \mathrm{mg}$. sodium folate ("folvite," Lederle) was given by subcutaneous injection on each of these days. No folic acid therapy was given the day before the test. Subjects fasted from nine hours before until after the completion of the test. During this time water was allowed ; food and liquids other than water may affect serum turbidity readings and were withheld.

Test Procedure.-Five millilitres of venous blood were withdrawn from the fasting subject and allowed to clot in a sterile tube at $37^{\circ}$ C. A solution of sodium folate in $20 \mathrm{ml}$. of water containing the equivalent of $2 \mathrm{mg}$. folic acid was then drunk. This solution was prepared from an ampoule of sodium folate containing the equivalent of $15 \mathrm{mg}$. folic acid $/ \mathrm{ml}$.

TABLE I

CYTOLOGICAL, HAEMATOLOGICAL, AND CLINICAL FINDINGS

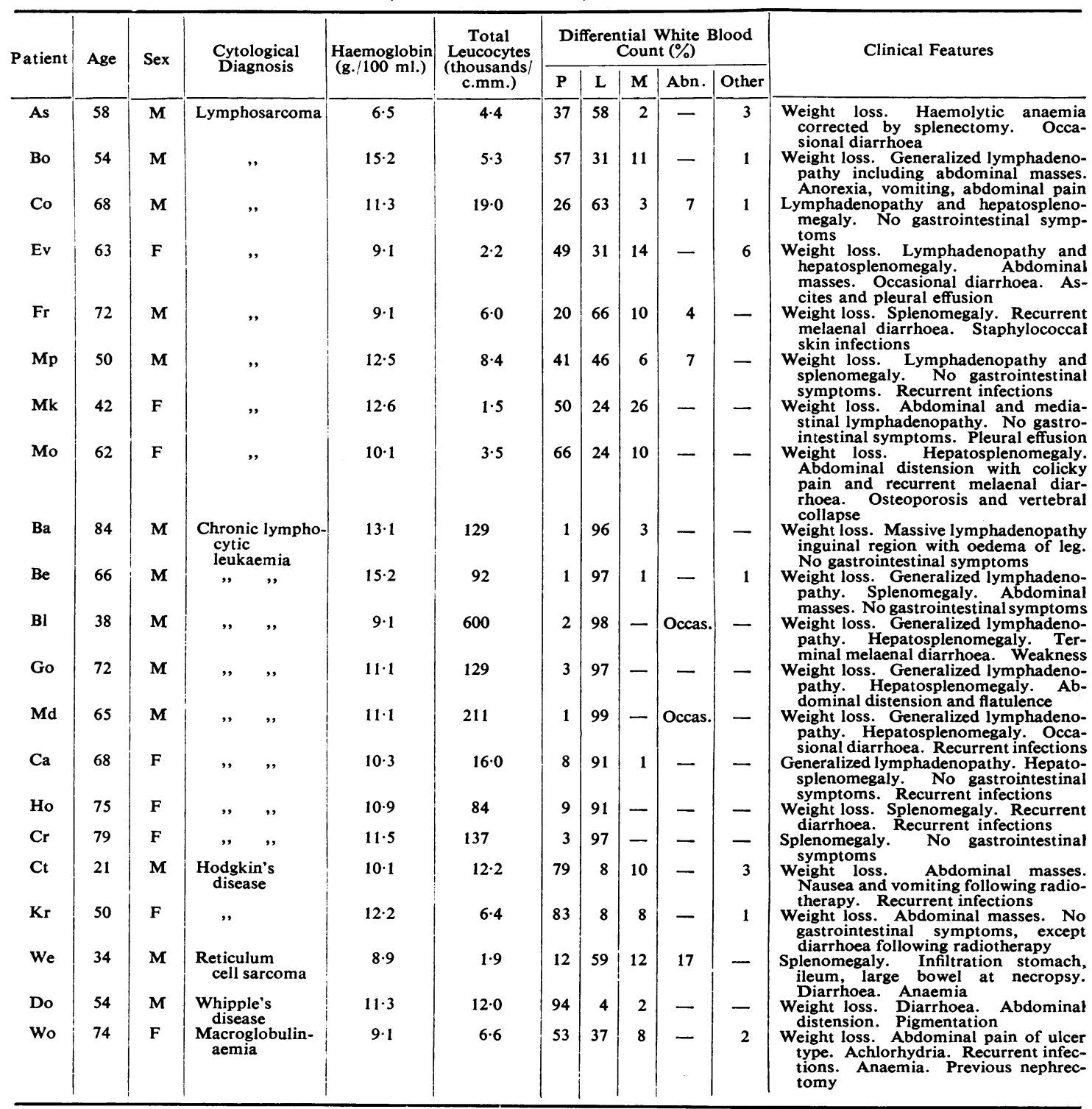


TABLE II

OTHER LABORATORY AND RADIOLOGICAL FINDINGS

\begin{tabular}{|c|c|c|c|c|c|c|c|c|c|c|}
\hline Patient & $\begin{array}{c}\text { Total } \\
\text { Serum } \\
\text { Protein }\end{array}$ & $\begin{array}{l}\text { Serum } \\
\text { Albumin }\end{array}$ & $\begin{array}{c}\text { Serum } \\
\text { Globulins }\end{array}$ & $\begin{array}{l}\text { Plasma } \\
\text { Carotene }\end{array}$ & $\begin{array}{l}\text { Daily } \\
\text { Faecal Fat } \\
\text { Excretion }\end{array}$ & $\begin{array}{l}\text { Percentage } \\
\text { Fat in } \\
\text { Faeces }\end{array}$ & $\begin{array}{c}\text { Xylose } \\
\text { Absorption }\end{array}$ & $\begin{array}{c}\text { Folic } \\
\text { Acid } \\
\text { Absorption }\end{array}$ & $\begin{array}{l}{ }^{58} \text { Co-B } \\
\text { Absorp- } \\
\text { tion }\end{array}$ & $\begin{array}{l}\text { Radiological } \\
\text { Findings }\end{array}$ \\
\hline $\begin{array}{c}\text { Normal } \\
\text { values }\end{array}$ & $\begin{array}{c}6 \cdot 0-7 \cdot 5 \\
\mathrm{~g} \cdot / 100 \mathrm{ml}\end{array}$ & $\begin{array}{c}3 \cdot 5-5 \cdot 5 \\
\text { g. } 100 \mathrm{ml}\end{array}$ & $\begin{array}{l}1 \cdot 5-3 \cdot 5 \\
\text { g. } 100 \mathrm{ml} .\end{array}$ & $\begin{array}{c}\text { Over } 70 \\
\mu \mathrm{g} .100 \mathrm{ml}\end{array}$ & $\begin{array}{l}\text { Less than } \\
5 \text { g./Day }\end{array}$ & $\begin{array}{l}\text { Less than } \\
25 \%\end{array}$ & $\begin{array}{l}\text { Greater } \\
\text { than } 4 \mathrm{~g} \text {. in } \\
\text { 5-Hour } \\
\text { Urine }\end{array}$ & $\begin{array}{c}\text { Serum } \\
\text { Peak } \\
70-130 \\
\mu \mathrm{mg} . \mathrm{ml}\end{array}$ & $\begin{array}{l}\text { Urinary } \\
\text { Excre- } \\
\text { tion } \\
16-36 \%\end{array}$ & \\
\hline $\begin{array}{l}\text { As } \\
\text { Bo }\end{array}$ & $\begin{array}{l}6 \cdot 2 \\
6 \cdot 4\end{array}$ & $\begin{array}{l}3 \cdot 3 \\
2 \cdot 9\end{array}$ & $\begin{array}{l}2 \cdot 9 \\
3 \cdot 5\end{array}$ & $\overline{41}$ & $6 \cdot 7$ & - & $\overline{6.9}$ & $\begin{array}{l}48 \\
65\end{array}$ & - & $\begin{array}{l}\text { Stomach normal } \\
\text { Mucosal thickening of } \\
\text { stomach. Normal } \\
\text { jejunal pattern }\end{array}$ \\
\hline $\begin{array}{l}\text { Co } \\
\text { Ev } \\
\text { Fr }\end{array}$ & $\begin{array}{l}6 \cdot 6 \\
4 \cdot 5 \\
6 \cdot 8\end{array}$ & $\begin{array}{l}3 \cdot 1 \\
2 \cdot 2 \\
2 \cdot 3\end{array}$ & $\begin{array}{l}3 \cdot 5 \\
2 \cdot 3 \\
4 \cdot 5\end{array}$ & $\begin{array}{r}157 \\
53 \\
60\end{array}$ & E & $\begin{array}{l}10 \\
62 \\
27\end{array}$ & $\begin{array}{l}\overline{2 \cdot 5} \\
5 \cdot 9\end{array}$ & $\begin{array}{l}60 \\
10 \\
28\end{array}$ & $\begin{array}{l}19 \cdot 2 \\
19 \cdot 3 \\
26 \cdot 3\end{array}$ & $\begin{array}{l}\text { Duodenal diverti- } \\
\text { culum. Abnormal } \\
\text { jejunal pattern }\end{array}$ \\
\hline $\begin{array}{l}\text { Mp } \\
\text { Mk } \\
\text { Mo }\end{array}$ & $\begin{array}{l}6 \cdot 0 \\
6 \cdot 4 \\
7 \cdot 9\end{array}$ & $\begin{array}{l}2 \cdot 2 \\
2 \cdot 7 \\
1 \cdot 8\end{array}$ & $\begin{array}{l}3 \cdot 8 \\
3 \cdot 7 \\
6 \cdot 1\end{array}$ & $\begin{array}{l}16 \\
27 \\
27\end{array}$ & $\frac{-}{1 \cdot 9}$ & $\frac{32}{6 \cdot 4}$ & $\begin{array}{l}5 \cdot 7 \\
6 \cdot 3 \\
2 \cdot 6\end{array}$ & $\begin{array}{l}18 \\
82 \\
38\end{array}$ & $\begin{array}{r}\overline{4 \cdot 7} \\
14 \cdot 4\end{array}$ & $\begin{array}{l}\text { Normal stomach and } \\
\text { jejunal pattern. } \\
\text { Gross osteoporosis }\end{array}$ \\
\hline $\mathrm{Ba}$ & $5 \cdot 6$ & $2 \cdot 2$ & $3 \cdot 4$ & 83 & - & - & $2 \cdot 5$ & 20 & - & - \\
\hline $\mathrm{Be}$ & - & - & 一 & - & 一 & - & - & 12 & - & $\begin{array}{l}\text { Normal stomach and } \\
\text { jejunal pattern }\end{array}$ \\
\hline $\begin{array}{l}\text { Bl } \\
\text { Go }\end{array}$ & $\begin{array}{l}5 \cdot 9 \\
6 \cdot 9\end{array}$ & $\begin{array}{l}3 \cdot 6 \\
4 \cdot 4\end{array}$ & $\begin{array}{l}2 \cdot 3 \\
2 \cdot 5\end{array}$ & $\overline{56}$ & - & $\overline{36}$ & $\overline{2 \cdot 9}$ & $\begin{array}{l}24 \\
66\end{array}$ & - & $\begin{array}{l}\text { Normal stomach and } \\
\text { jejunal pattern }\end{array}$ \\
\hline Md & $5 \cdot 5$ & $2 \cdot 6$ & $2 \cdot 9$ & 42 & $6 \cdot 2$ & 49 & $2 \cdot 1$ & 20 & $6 \cdot 7$ & $\begin{array}{l}\text { Normal jejunal } \\
\text { pattern }\end{array}$ \\
\hline $\mathrm{Ca}$ & $5 \cdot 7$ & $3 \cdot 2$ & $2 \cdot 5$ & 52 & - & 9 & $5 \cdot 7$ & 182 & - & Normal stomach and \\
\hline $\begin{array}{l}\mathrm{Ho} \\
\mathrm{Cr} \\
\mathrm{Ct} \\
\mathrm{Kr} \\
\mathrm{We}^{*}\end{array}$ & $\begin{array}{l}6 \cdot 3 \\
6 \cdot 9 \\
8 \cdot 0 \\
6 \cdot 9 \\
-\end{array}$ & $\begin{array}{l}3 \cdot 0 \\
2 \cdot 9 \\
2 \cdot 9 \\
3 \cdot 4 \\
-\end{array}$ & $\begin{array}{l}3 \cdot 3 \\
4 \cdot 0 \\
5 \cdot 1 \\
3 \cdot 5 \\
-\end{array}$ & $\begin{array}{r}24 \\
123 \\
22 \\
33 \\
-\end{array}$ & $\begin{array}{l}E \\
z \\
z\end{array}$ & $\begin{array}{l}7 \cdot 2 \\
15 \\
25 \cdot 2 \\
28 \\
-\end{array}$ & $\begin{array}{c}\text { Incontinent } \\
2 \cdot 3 \\
5 \cdot 3 \\
4 \cdot 8\end{array}$ & $\begin{array}{r}32 \\
116 \\
44 \\
35 \\
8\end{array}$ & $\overline{24 \cdot 1}$ & $\begin{array}{c}\text { Jejunal pattern } \\
\text { Normal stomach } \\
-\end{array}$ \\
\hline Do & $5 \cdot 0$ & $2 \cdot 3$ & $2 \cdot 7$ & 3 & 16 & - & $2 \cdot 1$ & 52 & Normal† & Abnormal jejunal \\
\hline Wo & 6.9 & $2 \cdot 6$ & $4 \cdot 3$ & 155 & - & - & $3 \cdot 8$ & 180 & $28 \cdot 6$ & $\begin{array}{l}\text { Normal sto mach and } \\
\text { jejunal pattern }\end{array}$ \\
\hline
\end{tabular}

* This patient had been receiving oral folic acid therapy for a month before the test. $\quad$ Faecal excretion test used. $0.68 \mu \mathrm{g}$. of a $1 \mu \mathrm{g}$. oral dose ${ }^{58} \mathrm{Co}-\mathrm{B}_{12}$ was absorbed.

The folic acid content of an ampoule of the same batch number had been checked previously by assaying against a preparation of crystalline folic acid (Light) stated to be at least $99 \%$ pure. Blood samples were withdrawn at hourly intervals for three hours. Serum from all four blood samples was stored at $-20^{\circ}$ C. until tested for folic acid content.

Assay of Folic Acid.-Serum folic acid activity was estimated microbiologically using a mutant strain of Streptococcus lactis R (A.T.C.C. 8043). The mutant strain is approximately three times as sensitive to folic acid as the standard strain. The technique used was essentially that of Teply and Elvehjem (1945). Growth turbidity was recorded with an EEL nephelometer.

Other Tests Used.-Other tests included radioactive vitamin $B_{12}$ absorption (Pitney and Stokes, 1958), xylose absorption (Benson, Culver, Ragland, Jones, Drummey, and Bougas, 1957), and estimations of faecal fat, serum proteins and plasma carotene by standard methods. Fat balances were estimated by the method of Frazer (1956). In some patients radiological examination of the stomach and small bowel was also performed. In a few patients estimations of serum calcium and inorganic phosphate were obtained.

\section{Subjects Studied}

Folic acid absorption tests were carried out on 19 normal subjects.

A combination of tests, including the folic acid test in all instances, was performed on eight patients suffering from lymphosarcoma, eight suffering from chronic lymphocytic leukaemia, and five with miscellaneous related conditions. Brief clinical and haematological notes on these patients are included in Table $I$, and the relevant laboratory results in Table II.

The diagnosis of lymphosarcoma was proved in all cases by histological examination of biopsy material In five patients the peripheral blood was free of abnormal cells; three showed some abnormal cells, but the appearances were not those of lymphocytic leukaemia. One patient (As) had significant anaemia, which was due to splenic hypersequestration and responded to splenectomy. Clinically, seven of the eight had recent weight loss, and five symptoms referable to the gastrointestinal tract. In one (Bo) these consisted of anorexia and pain suggestive of peptic ulcer. However, he had no diarrhoea or intestinal colic. Two (As and Ev) had mild, transitory bouts of diarrhoea, and in a third (Fr) there was a past history of recurrent melaena. In one patient only 
(Mo) were bowel symptoms prominent; she had repeated episodes of diarrhoea with melaena requiring blood transfusion.

The eight patients with chronic lymphocytic leukaemia all had blood counts typical of this condition (Table I). Six had recently lost weight, two (Md and Ho) had mild transient diarrhoea, and one (Go) abdominal distension with flatulence and vague abdominal pain. Melaena was present in one patient (Bl) who developed terminal melaenal diarrhoea.

The five patients with miscellaneous related conditions comprised two patients suffering from Hodgkin's disease, and one each with reticulum cell sarcoma, Whipple's disease, and macroglobulinaemia. Both patients with Hodgkin's disease had recent weight loss, but no gastrointestinal symptoms except transient nausea and vomiting in one and diarrhoea in the other following radiotherapy. Diarrhoea was a prominent symptom of the patient with reticulum cell sarcoma. The patient with Whipple's disease is to be reported in full elsewhere (Maddocks, Ralston, and Weiden, 1960). This patient had clinical malabsorption and steatorrhoea. The diagnosis was established by peroral suction biopsy of the small bowel. The patient with macroglobulinaemia has been included in this series as this condition is thought by some to represent a variant of lymphosarcoma, although she had no clinical signs of this disease. Details of this patient have been published previously (Pitney, O'Sullivan, and Owen, 1958).

No patient in any group had clinical or radiological evidence of primary intestinal tumour, although some had palpable masses due to enlarged mesenteric lymph nodes. One patient (Bo) had radiographic appearances suggestive of gastric lymphosarcoma, but these appeared late in his disease, and there were no signs of small bowel infiltration. None of the patients had associated megaloblastic anaemia. They were studied at a random time during the course of their disease, but wherever possible when they were not receiving active treatment. Some had, however, received prior treatment with nitrogen mustard, " chlorambucil," or radiotherapy.

Finally, folic acid absorption tests were also carried out on four patients suffering from extensive metastatic carcinoma of non-alimentary origin. These patients were not studied fully, and are not discussed in detail below.

\section{Results}

(1) Folic Acid Absorption Tests.-The results are as follows:

Normal Subjects. - Measurable folic acid activity could be demonstrated in every serum sample obtained from 19 normal adults for three hours after an oral dose of sodium folate containing the equivalent of $2 \mathrm{mg}$. folic acid. In 17 , the peak serum concentration was found at the end of the first hour. In the remaining two subjects, the peak occurred at the second hour. Serum concentrations were falling rapidly by the third hour.

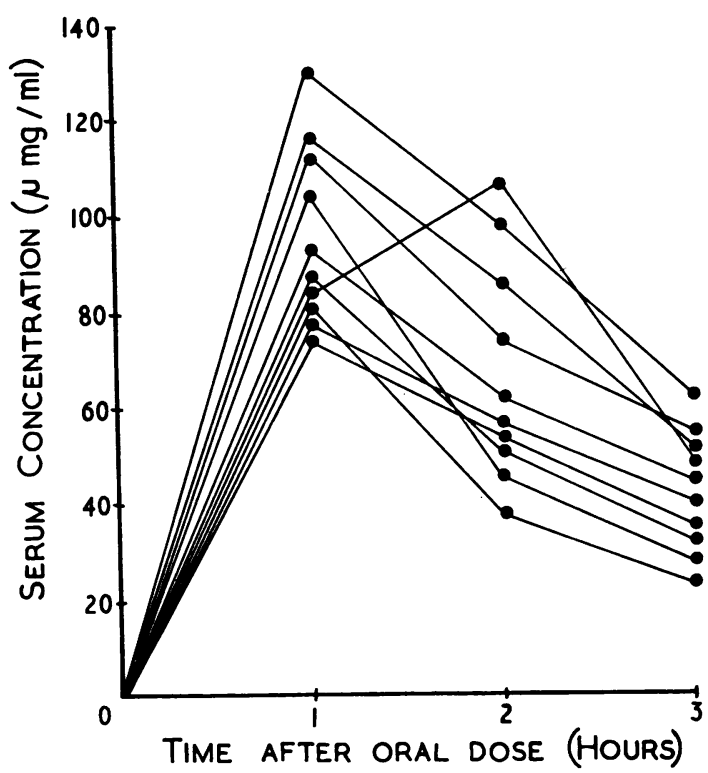

FIG. 1.-Serum folic acid concentrations in 10 normal subjects following a standard oral dose of sodium folate containing the equivalent of $2 \mathrm{mg}$. folic acid.

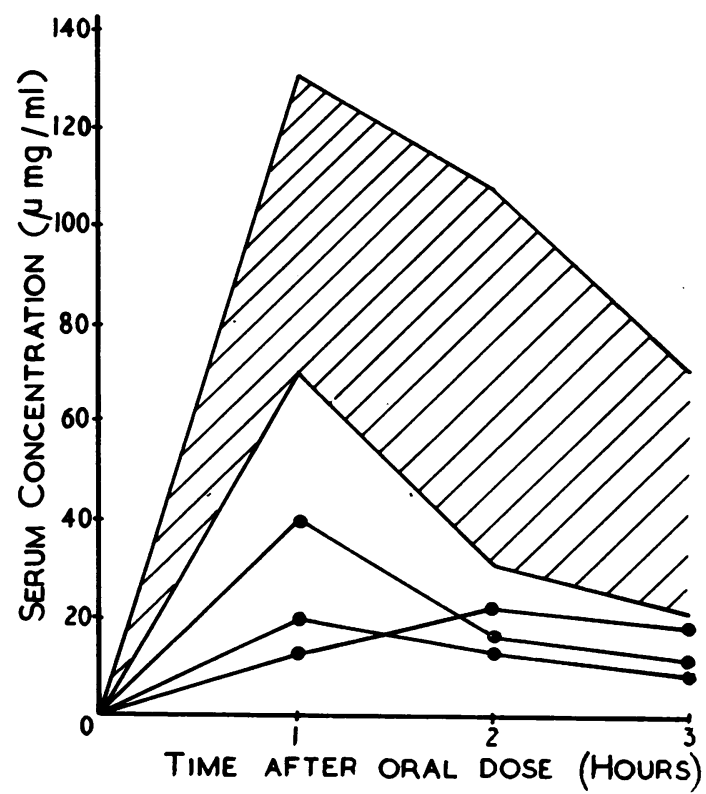

FIG. 2.-Serum folic acid concentrations in three normal subjects who received one half the standard dose. The shaded area represents the normal range of values obtained with the standard oral dose. 


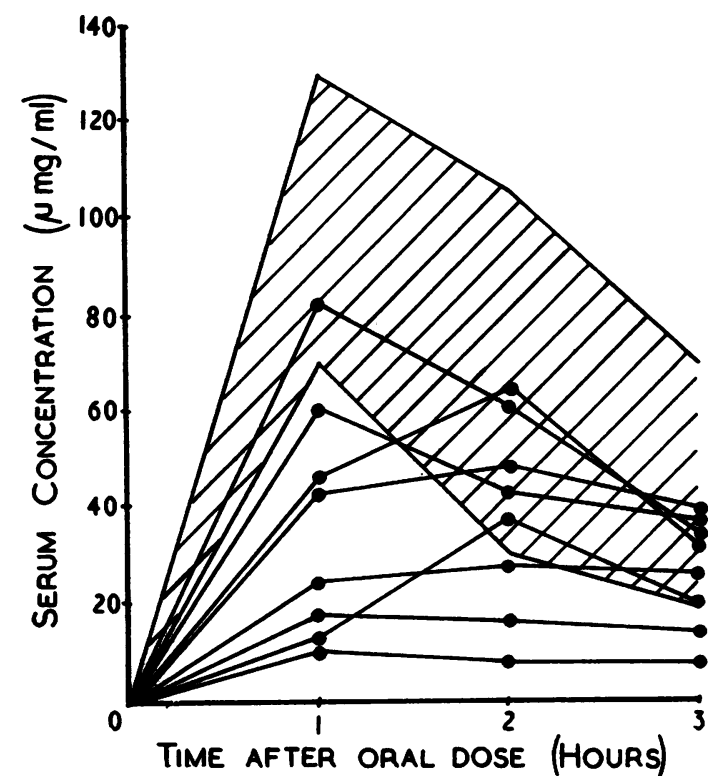

FIG. 3.-Serum folic acid concentrations in eight patients with lymphosarcoma.

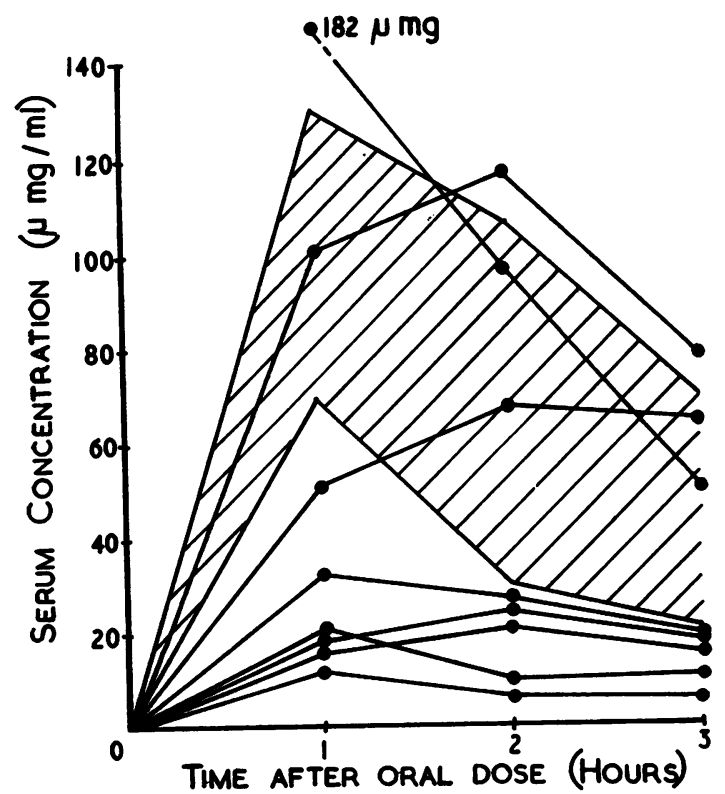

FIG. 4.-Serum folic acid concentrations in eight patients with chronic lymphocytic leukaemia.
The peak concentrations attained ranged from 70 to $130 \mu \mathrm{mg}$. folic acid per millilitre of serum. Fig. 1 shows a selection of 10 normal folic acid absorption curves which are representative of the group. This selection includes the highest and lowest curves obtained in the 19 normal subjects.

Measurable serum folic acid activity was obtained in normal subjects after $1 \mathrm{mg}$. orally, but the curves were flatter (Fig. 2). The three subjects shown in this figure were tested subsequently with the $2 \mathrm{mg}$. dose and the absorption curves fell within the limits shown in Fig. 1. After these experiments, a standard dose of sodium folate containing the equivalent of $2 \mathrm{mg}$. folic acid was used in all instances. A peak serum concentration less than $60 \mu \mathrm{mg} . / \mathrm{ml}$. was considered abnormal.

Patients with Lymphosarcoma.-In Fig. 3 are shown the absorption curves given by the eight patients suffering from lymphosarcoma. Five of the eight patients showed subnormal peak serum folic acid concentrations. Four of the five patients with possible small bowel involvement on clinical grounds showed subnormal peak concentrations, as did five of the seven with recent significant weight loss.

Patients with Chronic Lymphocytic Leukaemia. - The absorption curves of the eight patients with chronic lymphosytic leukaemia are shown in Fig. 4. Five showed subnormal peak serum concentrations. These five all had significant weight loss. Three of the four patients with symptoms suggestive of small bowel involvement produced abnormal curves. One patient $(\mathrm{Ca})$ had an abnormally high peak serum concentration. She was receiving treatment for a urinary tract infection at the time of investigation. This is discussed more fully below.

Patients with Miscellaneous Conditions.-The absorption curves of these patients are shown in Fig. 5. The two patients with Hodgkin's disease both showed subnormal peak serum concentrations. One of these patients $(\mathrm{Kr})$ was, however, receiving radiotherapy to the abdomen at the time of the test for para-aortic lymphadenopathy and had temporary diarrhoea. Both were losing weight steadily. The absorption curve of patient We was very flat with a peak serum concentration of $8 \mu \mathrm{mg} . / \mathrm{ml}$. This patient had moderate diarrhoea and post-mortem examination later showed extensive infiltration of the bowel with neoplastic cells. The patient with Whipple's disease (Do) also showed a subnormal peak serum concentration. He had steatorrhoea and a true clinical malabsorption syndrome. The 


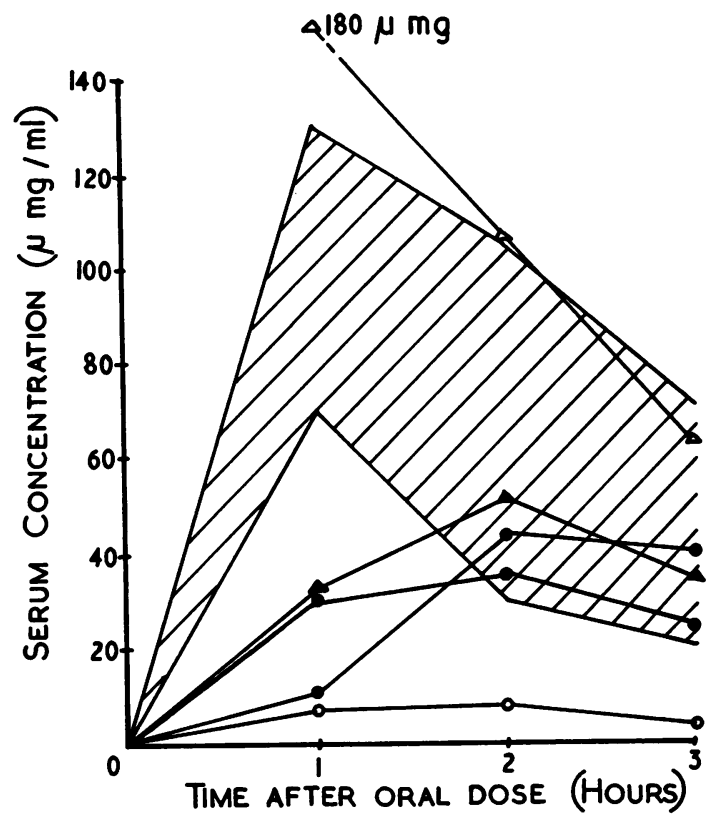

FIG. 5.-Serum folic acid concentrations in patients with Hodgkin's disease (O-O), reticulum cell sarcoma (O-O), Whipple's disease $(\boldsymbol{\Delta}-\mathbf{\Lambda})$, and macroglobulinaemia $(\Delta-\Delta)$.

patient with macroglobulinaemia (Wo) had an abnormally high peak serum concentration. It is of interest that she had undergone nephrectomy some years previously.

The four patients with disseminated carcinoma all showed peak serum folic acid concentrations within the normal range.

(2) Other Investigations.-Results of the other investigations suggested frequent gastrointestinal involvement in the patients studied.

The serum albumin concentration was below $3.5 \mathrm{~g}$. per $100 \mathrm{ml}$. in 17 of 19 patients studied, and below $3.0 \mathrm{~g}$. per $100 \mathrm{ml}$. in 12 of these. All patients with lymphosarcoma had some hypoalbuminaemia, as did five of the seven with chronic lymphocytic leukaemia. No patient in any group revealed hypoglobulinaemia, but increased serum globulin was present in four of eight with lymphosarcoma, and one patient each with chronic lymphocytic leukaemia, Hodgkin's disease, and macroglobulinaemia. This frequent occurrence of hyperglobulinaemia meant that, despite the frequent low serum albumin concentrations, the total serum protein levels were below $6.0 \mathrm{~g}$. per $100 \mathrm{ml}$. in only six of 19 patients, four of whom were suffering from chronic lymphocytic leukaemia. Statistical analysis showed no significant relation between serum albumin or globulin levels and low peak serum folic acid concentrations, but the association between hypoproteinaemia and diminished folic acid absorption was significant at the $5 \%$ level.

Diminished fat absorption was suggested in 13 of 17 patients by low plasma carotene concentrations (less than $70 \mu \mathrm{g}$. per $100 \mathrm{ml}$.), and biochemical steatorrhoea was shown in seven of 12 by increased faecal fat contents in random faecal specimens. Complete six-day fat balances confirmed steatorrhoea in three of four patients. The patient with a normal fat balance (Mo) was, however, unable to tolerate a diet containing $50 \mathrm{~g}$. fat daily, and this result must therefore be considered equivocal. The three groups of patients did not differ significantly in these results, nor was there significant correlation between either low plasma carotene levels or high faecal fat contents and low peak serum folic acid concentrations.

Xylose absorption tests were performed on 15 patients, and impaired carbohydrate absorption demonstrated in eight. The results showed some differences in the three groups of patients. Only two of six with lymphosarcoma had abnormal xylose absorption tests, while abnormal xylose tests were shown in four of five with chronic lymphocytic leukaemia. There was again no significant correlation between xylose absorption and peak serum folic acid concentrations.

The other investigations may be mentioned briefly. Four of 10 patients investigated were found to have defective ${ }^{58} \mathrm{Co}-\mathrm{B}_{12}$ absorption. The radioactive vitamin $B_{12}$ was given orally without intrinsic factor and the defective absorption could have been due to either deficiency of endogenous intrinsic factor secretion or to defective absorption of the vitamin $B_{12}$-intrinsic factor complex. Only one patient of seven studied (Do, with Whipple's disease) had hypocalcaemia. Radiological studies suggested lymphosarcomatous infiltration of the stomach in one patient (Bo), although he had a normal small bowel pattern. The typical segmentation pattern of the malabsorption syndrome was seen in only two of nine patients, one with lymphosarcoma and one with Whipple's disease.

Comparison of the folic acid absorption test with the other biochemical parameters used is difficult, for in these patients, as is usually the case in studies of intestinal absorption, the biochemical profiles varied in apparently random fashion from patient to patient. In general terms, however, the folic acid absorption test appeared to be the most sensitive of the methods used in this study, and in all patients with low peak serum folic acid concentrations collateral evidence of malabsorption was obtained, and such patients tended to show 
evidence of multiple absorptive defects. Thus, all patients, except $\mathrm{Ca}$, with a total serum protein concentration below 6.0 g. per $100 \mathrm{ml}$. had abnormal folic acid absorption tests. Of the 21 patients studied in detail, low peak serum folic acid concentrations were observed in 14, while hypoproteinaemia was found in six of 19, biochemical steatorrhoea in nine of 14 , and depressed xylose absorption in eight of 15 . Low plasma carotene levels were frequent, but difficult to interpret in patients who were frequently anorexic.

\section{Discussion}

The folic acid absorption test described in this paper differs in some respects from that reported by Chanarin, Anderson, and Mollin (1958). We consider it important to fast the patient in the strict sense. Even the amount of milk contained in a cup of tea may alter the turbidity of serum as recorded by a nephelometer, and the usual light breakfast containing buttered toast may cause naked-eye turbidity of serum. The inclusion of a preliminary serum blank in the assay of test serum samples allows correction to be made for non-specific turbidity. Chanarin and co-workers used a test dose of crystalline folic acid dissolved in dilute alkali. Folic acid is likely to be precipitated out of this solution in the acid milieu of the gastric contents. "Folvite" appears to be more stable at low $p \mathrm{H}$ and is probably absorbed more rapidly. This may explain why 17 of the 19 normal subjects reported in this paper showed peak serum levels after the first hour, whereas the controls of the workers mentioned above showed peaks mostly at the second hour. A $2 \mathrm{mg}$. dose of folic acid as "folvite" gave similar serum values to those described by Chanarin et al. using a $3 \mathrm{mg}$. dose of folic acid dissolved in dilute alkali. A $2 \mathrm{mg}$. oral dose gave more satisfactory curves than a $1 \mathrm{mg}$. dose (Fig. 2).

The serum concentration of folic acid in these tests is influenced by the amount of folic acid absorbed from the intestine during the time of testing, the rate of deviation to the tissues and the rate of renal excretion of folic acid. In renal failure delayed excretion of folic acid might be expected and we have found abnormally high peak serum concentrations in patients with uraemia. Patient Ca (Fig. 4) was suffering from pyelonephritis at the time the test was performed, and patient Wo (Fig. 5) had undergone a previous nephrectomy. Coexisting renal disease is probably a contraindication to this test.

The possibility has been considered that the subnormal folic acid absorption curves observed in this investigation were due to increased tissue requirements for folic acid rather than defective absorption. Pollack, Taylor, and Williams (1942) found higher amounts of folic acid in various types of neoplastic tissue than in the corresponding normal tissue, and Swendseid et al. (1951) found higher concentrations of folic acid in leukaemic leucocytes than in normal white cells. Increased tissue requirements does not seem a satisfactory explanation since the four patients with disseminated carcinoma tested presumably also had increased tissue demands for folic acid but all showed normal absorption curves.

Inadequate loading with folic acid before the absorption tests is an unlikely explanation for the subnormal curves. Urinary excretion of folic acid was measured in two normal subjects who each received injections of $15 \mathrm{mg}$. folic acid on three successive days. This is the loading procedure used in preparation of patients for the tests. Total three-day urinary excretion values in these normal subjects were 17.9 and $19.3 \mathrm{mg}$. respectively. Assuming that biliary or intestinal loss of folic acid was not significant, these subjects retained more than one half of the total $45 \mathrm{mg}$. folic acid injected. The highest concentration of total apparent folic acid activity in the body is stated to be in the liver and the concentration in this organ is normally in the range from 1.3 to $5.8 \mu \mathrm{g} . / \mathrm{g}$. wet tissue (Girdwood, 1952, 1953). A normal liver thus contains no more than $10 \mathrm{mg}$. material with folic acid activity. The loading injections would be expected to more than double the normal body stores.

Finally, the results of other absorption tests in these patients support the view that the low folic acid curves were indeed the result of impaired intestinal absorption, and suggest further that the folic acid absorption test may be the most sensitive single test of intestinal absorption, at least in this group of patients. It would therefore appear that unselected patients suffering from lymphosarcoma and chronic lymphocytic leukaemia commonly show laboratory evidence of intestinal malabsorption. In the majority of our patients there were no clinical signs of severe gastrointestinal involvement. Certainly the typical sprue syndrome was seen in only one patient. Malabsorption could explain some of the puzzling clinical features associated with terminal lymphosarcoma. Ascites and oedema of the lower extremities are often ascribed to pressure from enlarged abdominal lymph nodes. In these patients hypoproteinaemia is common and impaired protein absorption or exudative enteropathy (Gordon, 1959) might offer an alternative mechanism. We have found that 
such patients are often improved after intravenous therapy with salt-poor concentrated serum albumin. Weight loss, which is often a prominent feature in both lymphosarcoma and chronic lymphocytic leukaemia, is also common with intestinal malabsorption. The occasional development of megaloblastic anaemia in these patients could be due to malabsorption of folic acid as well as to the increased demands of proliferating neoplastic tissue for folic acid.

We wish to thank Sister A. Smith and Dr. M. F. Carruthers for their help in the preparation of the patients, and Mr. R. E. Davis and Mr. P. Onesti for technical assistance with the microbiological assays. Dr. D. H. Curnow carried out the biochemical estimations.

\section{REFERENCES}

Benson, J. A., Jr., Culver, P. J., Ragland, S., Jones, C. M., Drummey, G. D., and Bougas, E. (1957). New Engl. J. Med., 256, 335.

Chanarin, I., Anderson, B. B., and Mollin, D. L. (1958). Brit. J. Haemat., 4, 156.

Mollin, D. L., and Anderson, B. B. (1958). Ibid., 4, 435.

Fairley, N. H., and Mackie, F. P. (1937). Brit. med. J., 1, 375.

Frazer, A. C. (1956). The Association of Clinical Pathologists Broadsheet No. 9.

Girdwood, R. H. (1952). Biochem. J., 52, 58.

- (1953). Blood, 8, 469.

Gordon, R. S., Jr. (1959). Lancet, 1, 325.

Maddocks, I., Ralston, M., and Weiden, S. (1960). Gastroenterology. In press.

Pitney, W. R., O'Sullivan, W. J., and Owen, J. A. (1958). Brit. med. J., 2, 1508.

- and Stokes, J. B. (1958). Aust. Ann. Med., T, 126.

Pollack, M. A., Taylor, A., and Williams, R. J. B. (1942). Univ. of Texas Publication No. 4237, p. 56.

Skrimshire, J. F. P. (1955). Quart. J. Med., n.s. $24,203$.

Sleisenger, M. H., Almy, T. P., and Barr, D. P. (1953). Amer. J. Med., 15, 666 .

Spellberg, M. A., and Zivin, S. (1949). Arch. intern. Med., 83, 135.

Swendseid, M. E., Bethell, F. H., and Bird, O. D. (1951). Cancer Res., 11, 864.

Teply, L. J., and Elvehjem, C. A. (1945). J. biol. Chem., 157, 303. 